\author{
Наталија Ј. Брајковић \\ Филозофски факултет, Никшић, Црна Гора \\ natalijab@t-com.me
}

\title{
АПАРАТУРА ИНДИВИДУАЛИЗАЦИЈЕ У УЏБЕНИЦИМА РУСКОГ ЈЕЗИКА ОРБИТА И РОДНИЧОК И ОСТАЛИМ ЕЛЕМЕНТИМА НАВЕДЕНИХ УЏБЕНИЧКИХ КОМПЛЕТА
}

\author{
Anстракт
}

У датом раду извршили смо дескрипцију и анализу осам уџбеника руског језика (укључујући пратеће уџбеничке компоненте анализираних уџбеничких структура) из уџбеничких комплета Орбита и Родничок који су (осим уџбеничких корпуса Давайте дружить! и Диалог) у употреби у основним школама Црне Горе и Србије у посљедњих двадесет година. Циљ овог рада превасходно се огледа у сагледавању неких релевантних, корисних и ваљаних сегмената, чијим тумачењем и анализом бисмо понудили адекватан приступ осмишљавању, конципирању и реализацији уџбеника страних језика. Наше интенције огледају се и у настојању да датим радом учинимо што реалније и компетентније тумачење принципа индивидуализације $u$ диферениијације градива уграђених у анализиране школске књиге, да истакнемо бројне резултате истраживања апаратуре индивидуализације до којих смо дошли на основу валоризације наведених уџбеничких корпуса, као и да понудимо низ рјешења која обезбјеђују постизање разноврсних стратегија и нивоа индивидуализације.

Кључне ријечи: индивидуализација, диференцијација, уџбеник руског језика, наставни процес, семантизација лексичких јединица, основношколска узрасна формација.

\section{1. УВОД}

Бавећи се изучавањем концепције анализираних уџбеничких структура страног (руског) језика, као и њихових пратећих уџбеничких компонената, овом приликом одлучили смо да наше интересовање превасходно ус- 
мјеримо на сагледавање неких релевантних, корисних и ваљаних сегмената, чијим тумачењем и анализом бисмо понудили адекватан приступ осмишљавању, конципирању и реализацији уџбеника страних језика. Наше интенције огледају се и у настојању да датим радом учинимо што реалније и компетентније тумачење принципа индивидуализащчје и диференцијащчје градива уграђених у анализиране школске књиге.

Разматрајући два изабрана корпуса уџбеника руског језика настојаћемо да овом приликом објективно, критички и аналитички приђемо поступку писања, израде и остваривања уџбеничких структура страног језика и осталих пратећих компонената анализираних уџбеничких комплета, као и да утврдимо да ли индивидуализација и диференцијација налазе одраза на свим нивоима структуре и садржаја у њима.

Превасходно ћемо се позабавити сагледавањем апаратуре индивидуализације која је уграђена у анализиране школске књиге и остале елементе наведених уџбеничких комплета.

Током спровођења истраживања система уџбеничких структура језичку материју смо сагледавали и анализирали поступно, редом, према лекцијама датим у уџбенику. Вршећи наведену експертизу, превасходно смо се бавили реконструисањем информација о томе на који је начин дати ауторски тим издвојио и изабрао наставни материјал, како је осмислио активности између ученика и наставника у настави, као и на који начин је организовао сам процес учења и руковођење тим процесом.

Дакле, извршићемо дескрипцију и анализу уџбеника и осталих елемената уџбеничког комплета који су у употреби у основним школама Црне Горе и Србије у посљедњих двадесет година (Орбита - уџбеничка серија која се великим дијелом користи у црногорском основношколском систему), али ћемо учинити и кратак осврт на једну посве репрезентативну и монолитну савремену уџбеничку серију објављену у Републици Србији (Родничок, Београд, Завод за уџбенике), која за сад не налази примјену у црногорском основношколском образовном систему. Овом приликом ћемо истражити само оне компоненте уџбеничког комплета за које смо у нашој анализи установили да су се у прошлости активно користиле, али да су и данас у широкој употреби у српским/црногорским школама. Наша настојања огледају се и у тежњи да наставницима руског језика обезбиједимо што реалнију и компетентнију слику о структурама уџбеника Орбита (аутор: П. Пипер, М. Петковић и С. Мирковић) и уџбеника Родничок (аутори: љ. Поповић и Ј. Гинић) којима се служе у поступку реализације наставе руског језика. Тиме ћемо допринијети остваривању боље и квалитетније комуникативне компетенције основношколске ученичке узрасне формације. Уџбеници који су подвргну- 
ти експертизи чине једну својеврсну „уџбеничку синтезу“ са аудио-касетом, Радном свеском и Приручником за наставнике. Оно што ћемо у вези са овим истаћи јесте податак до ког смо нашом анализом дошли да већина школа у Црној Гори не посједује, нити користи у настави ни Приручник, ни аудио-касете.

Рад на конципирању, осмишљавању и презентовању ових уџбеничких система подразумијевао је велики уложени труд и енергију и као такав заслужује и похвале и признања. Наше тежње превасходно се огледају у томе да, на основу детаљног сагледавања цјелокупног садржаја наведених уџбеника руског језика за основну школу (Орбита, Родничок - за V, VI, VII и VIII разред, аутори - П. Пипер, М. Петковић и С. Мирковић; односно Љ. Поповић и Ј. Гинић) утврдимо у њима степен присуства индивидуализације и диференцијащије као релевантног дидактичког начела.

У уџбеницима руског језика за основну школу (Opбита), који се активно примјењују у српској/црногорској језичкој и социокултурној средини, тематика је ведра и блиска ученицима, у њима се тумаче и приказују сегменти и теме из свакодневног живота. Наведене уџбеничке структуре карактерише тематска сређеност и систематичност. Лексика која се у њима третира и тумачи, корисна је за практични живот. Граматика је ваљано и умјешно испреплетана са задацима и фразеологијом, блиским и занимљивим ученицима. Текстови су лијепо интерпретирани садржајним цртежима, сликама, фотографијама. У почетним уџбеницима језик треба својим стилом да одговара узрасту ученика, да не буде ни књишки апстрактан, нити тежак, ни исувише дјетињаст, инфантилан (Радошевић 1970).

Аутори уџбеника настојали су да презентују уџбеничку грађу одржавајући тематско-лексички лингвокултуролошки континуитет од разреда до разреда по принципу „малих“ корака, тј. поступком од лакшег ка тежем.

Орбита, уџбеник руског језика за основну школу (V, VI, VII и VIII разред, аутори, П. Пипер, М. Петковић и С. Мирковић, Завод за уџбенике, Београд, 2007, 2008, 2005. и 2010) конципиран је у складу са поставкама савременог свјесно-практичног, когнитивног и комуникативног приступа у настави руског језика. Формиран је у складу са савременом концепцијом грађења уџбеника страног/руског језика и по модерним дидактичко-методичким критеријумима. Текстови у њему чине репрезентативне обрасце на лингвистичком и културолошком плану, актуелни су и приказују реално савремено стање руског језика и руске социокултурне и друштвене стварности.

Уџбеник руског језика за V разред основне школе (уџбеничке серије Opбита), заједно са Радном свеском и Приручником за наставнике, сагледавају, третирају и тумаче на свој начин проблем усвајања руског правописа. 
Остављајући пријатан и ведар визуелни утисак, дјелујући чистотом и оригиналношћу садржаја текста, говорећи о високом степену познавања дјечје психологије, уџбеник у великом степену настоји да побуди пажњу и интересовање ученика, претварајући рјешавање сложених и тешких проблема које са собом носи руска азбука у занимљиву игру. У намјери да се код дјеце изграде елементи филолошког расуђивања, наведени уџбеник пружа унификоване и аутентичне, по једноставности и неусиљености, обрасце како да се код ученика изгради јасна представа о томе шта је ријеч, глас, самогласник, наглашени слог и др. Уџбеници наведене уџбеничке серије (Opбита) представљају и јединствен примјер како монотона и компликована правила могу бити претворена у једноставна, и за дјецу занимљива сазнања (нпр. у уџбенику Орбита 5 тврди и меки сугласници, стр. 19; слова $e, я, ю$, , стр. 24; звучни и безвучни сугласници, стр. 38 итд.). Садржај текстова у складу je са узрастом и могућностима ученика $\mathrm{V}$ разреда. По нашем мишљењу, у уџбеничкој структури Орбите 5 требало би дати више мјеста и простора самосталности ученика у процесу слободног изражавања мисли. Конципирати упечатљив, лијеп, сугестиван, а истовремено рационално компонован уџбеник није нимало лак ни једноставан посао.

Родничок (корпус уџбеника руског језика за V, VI, VII и VIII разред основне школе, аутори Љ. Поповић и Ј. Гинић, Завод за уџбенике и наставна средства, Београд, 2007, 2008, 2009. и 2010) представља темељно и концизно обрађен језички садржај у циљу његовог студиозног усвајања. Лексика, грађење језичких форми и њихово коришћење у живој ријечи тумаче се и изучавају заједно. Уџбеници су прожети разноврсним идејама како да се сажето и језгровито представе особености језика у циљу њихове употребе у живој комуникацији. Карактерише их оптимално обиље лексичког градива, концизност плана и занимљиви и разноврсни задаци, који су углавном у служби богаћења рјечника, сакупљања стандардних облика и фразеологије, увјежбавања свакодневних форми изражавања, облика опхођења итд. Задаци у уџбеницима су јасни, једноставни, директни и прегледни и имају за циљ грађење активног владања језиком и увјежбавање најразноврснијих облика руског језика. Они се супротстављају рутинерству и формализму у обављању језичких активности. У датим уџбеницима доминира текст намијењен развоју говорних умијећа и навика ученика, који је неријетко пропраћен дијалозима на основну тему текста и многобројним вјежбама које имају за циљ активно усвајање језика и пасивну анализу облика.

Што се тиче новије уџбеничке серије Родничок, указаћемо на то да је она веома интересантна и концепцијски нешто другачија од серије Орбита. У њој се потенцира рад на рјешавању бројних проблема и потешкоћа које 
поставља реформа наставе страних језика. Структуре наведене уџбеничке серије су рационалније конципиране и осмишљене, уз веће усмјеравање пажње на процес овладавања живом ријечју. Вјежбе су у њима разноврсне, обликоване и структуриране на основу говорних модела, илустрација, дијалога. У њима се спроводи принцип активизације ученика у самосталном раду на свјесном овладавању руским језиком. Особита пажња се поклања достигнућима савремене науке и технологије. Теоријске основе наведене серије уџбеника све дубље залазе у суштинске одлике процеса усвајања руског језика као страног. Кроз текстове у њима, представљена је богата стилска разноврсност руске језичке структуре.

\section{1. АНАЛИЗИРАНИ КОРПУС УЏБЕНИКА РУСКОГ ЈЕЗИКА ЗА ОСНОВНУ ШКОЛУ И ОСТАЛИХ ЕЛЕМЕНАТА НАВЕДЕНИХ УџБЕНИЧКИХ КОМПЛЕТА}

Корпус уџбеника руског језика који је у овом раду био подвргнут процјени са различитих аспеката, подразумијева осам уџбеничких књига намијењених ученицима основношколског узрасног профила (укључујући пратеће уџбеничке компоненте анализираних уџбеничких комплета). То су сљедећи уџбеници:

а) Уибеници руског језика за основну школу објављени у српској говорној средини, а који се данас активно примјенују у ирногорском основношколском образовном систему:

1) П. Пипер, М. Петковић, С. Мирковић, Орбита - руски језик за 5. разред основне школе, Завод за уџбенике, Београд, 2007.

2) П. Пипер, М. Петковић, С. Мирковић, Орбита - руски језик за 6. разред основне школе, Завод за уџбенике и наставна средства, Београд, 2008.

3) П. Пипер, М. Петковић, С. Мирковић, Орбита - руски језик за 7. разред основне школе, Завод за уџбенике и наставна средства, Београд, 2005.

4) П. Пипер, М. Петковић, С. Мирковић, Орбита - руски језик за 8. разред основне школе, Завод за уџбенике и наставна средства, Београд, 2010.

б) Радне свеске из руског језика за основну школу објављене у српској говорној средини, а које се данас активно примјењују у ирногорском основношколском образовном систему:

1) П. Пипер, М. Петковић, С. Мирковић, Орбита - руски језик за 5. разред основне школе: радна свеска, Завод за уџбенике, Београд, 2007.

2) П. Пипер, М. Петковић, С. Мирковић, Орбита - руски језик за 6. разред основне школе: радна свеска, Завод за уџбенике, Београд, 2008. 
3) П. Пипер, М. Петковић, С. Мирковић, Орбита - руски језик за 7. разред основне школе: радна свеска, Завод за уџбенике, Београд, 2009.

4) П. Пипер, М. Петковић, С. Мирковић, Орбита - руски језик за 8. разред основне школе: радна свеска, Завод за уџбенике, Београд, 2010.

в) Приручници за наставнике из руског језика за основну школу објављени у српској говорној средини, а који се данас активно примјењују у ирногорском основношколском образовном систему:

1) П. Пипер, М. Петковић, С. Мирковић, Орбита - руски језик за 5. разред основне школе: приручник за наставнике, Завод за уџбенике, Београд, 2007.

2) П. Пипер, М. Петковић, С. Мирковић, Орбита - руски језик за 6. разред основне школе: приручник за наставнике, Завод за уџбенике, Београд, 2008.

3) П. Пипер, М. Петковић, С. Мирковић, Орбита - руски језик за 7. разред основне школе: приручник за наставнике, Завод за уџбенике, Београд, 2005.

4) П. Пипер, М. Петковић, С. Мирковић, Орбита - руски језик за 8. разред основне школе: приручник за наставнике, Завод за уџбенике, Београд, 2010.

2) Уибеници руског језика за основну школу објављени у српској говорној средини, који за сада не налазе примјену у ирногорском основношколском образовном систему:

1) Љ. Поповић, Ј. Гинић, Родничок - руски језик за 5. разред основне школе, Завод за уџбенике, Београд, 2007.

2) Љ. Поповић, Ј. Гинић, Родничок - руски језик за 6. разред основне школе, Завод за уџбенике, Београд, 2008.

3) Љ. Поповић, Ј. Гинић, Родничок - руски језик за 7. разред основне школе, Завод за уџбенике, Београд, 2009.

4) Љ. Поповић, Ј. Гинић, Родничок - руски језик за 8. разред основне школе, Завод за уџбенике, Београд, 2010.

д) Радне свеске из руског језика за основну школу објављене у српској говорној средини, које за сада не налазе примјену у ирногорском основношколском образовном систему:

1) Љ. Поповић, Ј. Гинић, Родничок - руски језик за 5. разред основне школе: радна свеска, Завод за уџбенике, Београд, 2007.

2) Љ. Поповић, Ј. Гинић, Родничок - руски језик за 6. разред основне школе: радна свеска, Завод за уџбенике, Београд, 2008. 
3) Љ. Поповић, Ј. Гинић, Родничок - руски језик за 7. разред основне школе: радна свеска, Завод за уџбенике, Београд, 2009.

4) Љ. Поповић, Ј. Гинић, Родничок - руски језик за 8. разред основне школе: радна свеска, Завод за уџбенике, Београд, 2010.

Ђ) Приручници за наставнике из руског језика за основну школу објављени у српској говорној средини, који за сада не налазе примјену у ирногорском основношколском образовном систему:

1) Љ. Поповић, Ј. Гинић, Родничок - руски језик за 5. разред основне школе: приручник за наставнике, Завод за уџбенике, Београд, 2007.

2) Љ. Поповић, Ј. Гинић, Родничок - руски језик за 6. разред основне школе: приручник за наставнике, Завод за уџбенике, Београд, 2008.

3) Љ. Поповић, Ј. Гинић, Родничок - руски језик за 7. разред основне школе: приручник за наставнике, Завод за уџбенике, Београд, 2009.

\section{2. РЕЗУЛТАТИ ЕКСПЕРТИЗЕ АНАЛИЗИРАНИХ КОРПУСА УЏБЕНИКА РУСКОГ ЈЕЗИКА ЗА ОСНОВНУ ШКОЛУ И АПАРАТУРА ИНДИВИДУАЛИЗАЦИЈЕ У ЊИМА}

Индивидуализација и диференцијација наставе се у уџбеник уграђује путем:

1) варијантности представљања текстова;

2) варијантности семантизаиије лексичких јединица;

3) индивидуализаиије преткомуникативне активности;

4) варијантности у поступцима планирања, осмишьвавања и организовања комуникативног рада;

5) груписања, селекиије и релативне слободе у редоследу тумачења и обрађивања уибеничке грађе (Кончаревић 2002: 170).

1) Варијантност представљања текстова огледа се у омогућавању примања језичких знања преко неколико канала перцепције, што заправо значи да се сваки уџбенички текст истовремено уводи и презентује у виду штампаног текста, звучног снимка и илустрације. То нам указује на чињеницу да је аспект индивидуализације утемељен у аспект оне унутрашње структуре сваке школске књиге. Радећи на истраживању поменутих уџбеничких корпуса за основну школу (Орбита и Родничок), у више наврата смо уочили представљање уџбеничке текстотеке путем неколико канала перцепције, нпр. у оралној настави текстови се презентују и аудитивно и графички, потом аудитивним, графичким и илустративним путем у приказивању главних текстова уџбеничких параграфа, који су снимљени на касети и визуелно представљени, графички и илустративно у представљању других текстуал- 
них садржаја, вјежбања и задатака. Све ово нас и упућује на закључак да анализирани уцбеници руског језика за основну школу пружају ваљане услове за остваривағе индивидуализације наставе.

2) Варијантност семантизације лексичких јединица значи да се она у уџбеничким структурама постиже на више начина: коришћењем визуелне очигледности, предочавањем контекста, коментара, дефиниције или појашњења на страном језику, превођењем на матерњи језик ученика, позивањем на творбену структуру, уочавањем унутарлексичке системности итд. У вези са овим осврнућемо се на јасан, концизан и амбициозан захтјев А. Р. Арутјунова који у вези са истицањем важности варирања начина семантизације лексике наглашава да се за сваку лексему која треба да уђе у продуктивни фонд представе најмање два поступка појашњавања њеног значења и примјене (Арутюнов 1987: 68; Кончаревић 2002: 171).

Сада ћемо се укратко осврнути на питање - како се у анализираним уибеницима руског језика за основну иколу постиже семантизација лексичких јединицьа?

У уџбеничкој структури уџбеника Oрбита 5, осим визуелне семантизације у илустрацијама оралног курса и букварског периода (нпр. стр. 17, $18,23)$, наилазимо и на друге поступке појашњавања значења ријечи: а) уз помоћ специјалних (намјенских) илустрација, укључених у састав разноврсних тематских рјечника (музички инструменти, стр. 27; зимска одјећа, стр. 55; боје и укуси, стр. 61; домаће и дивље животиње, стр. 85; објекти у граду и превозна средства, стр. 91-92); б) путем представљања лексема у тематским низовима (родбинска терминологија, стр. 33; име-име по оцу-презиме, стр. 34; доба дана/ноћи и годишња доба, стр. 85); в) упућивањем на унутарлексичку системност (стр. 62, антонимија); г) путем преводне семантизације ријечи и израза („Посмотри, как переводится“, стр. 58, 71, 74, 78, 84, 90, $96,97)$. Илустративним путем, на веома сликовит, инвентиван и креативан начин семантизују се поједине пословице (стр. 35, 109). У уџбенику Орбиma 6 лексичке јединице и изрази се семантизују: а) уз помоћ специјалних (намјенских) илустрација, укључених у састав разноврсних тематских рјечника (одјећа, стр. 58; дјелови лица, стр. 77); б) путем преводне семантизације ријечи и израза („Посмотри, как переводится“, стр. 12, 19, 27, 35, 39, 41, 42, 53, 56, 60, 69, 73, 75, 76, 85, 88, 90, 91, 96, 101, 103, 104, 113, 117, 125). У уџбеничкој структури уџбеника за 7. разред Орбита 7 семантизација одређеног броја ријечи се врши у одјељцима: „Слова и выражения“ (стр. 14, 19, 24, 33, 40-41, 49, 50, 51, 58, 60, 67, 71, 79, 80, 83, 85, 86, 90, 103, 106-107, 121, 125, 138, 139, 141, 143, 146, 151, 152-153, 154, 156, 166, 169, 173, 176, 187); „Обрати внимание“ (стр. 19) путем преводне семантизације 
ријечи и израза; у одјељку „Смотри, не ошибись!“ ученицима се појашњава међујезичка хомонимија и паронимија, другачији род и специфичност датих форми и облика (стр. 21, 24, 37, 57, 67, 132, 156, 173). Системско приказивање ријечи руског језика са илустративном семантизацијом може се уочити на стр. 181 (врсте дрвећа). Појашњавање значења руских ријечи уз помоћ специјалних (намјенских) илустрација укључених у састав разноврсних тематских рјечника може се уочити у анализираној школској књизи на стр. 45 , 46, 47 (спортске игре); одјећа, обућа и накит (стр. 56). У уџбенику Орбита 8 семантизација лексике је великим дијелом запостављена, појашњења значења руских лексичких јединица ученик добија у одјељцима „Посмотри, как переводится“ (стр. 17, 36, 73, 77, 93, 126); „Слова и выражения“ (стр. 93), док рубрика „Смотри, не ошибись!“ семантизује и тумачи ученицима поједине међујезичке хомониме (стр. 56).

У уџбенику Родничок 5, осим визуелне семантизације ријечи дате у илустрацијама оралног и букварског периода, могли смо уочити и друге поступке тумачења и појашњавања значења ријечи који се реализују: а) помоћу специјалних (намјенских) илустрација, најчешће укључених у тематске рјечнике (одјећа и обућа, стр. 84; дјелови тијела пса, стр. 90; дјелови људског тијела, стр. 99); б) уз помоћ презентације лексема у тематским низовима (родбинска терминологија, стр. 31); в) поступком упућивања на унутарлексичку системност (стр. 100, антонимија); г) помоћу преводне семантизације лексичких јединица, синтагми и реченица („Словарик“, стр. 11, 14, 19, $22,24,25,28,31,34,36,39,40,41,43,53,55,58,59,61,64,74,77,82,84,89$, 91, 93, 98, 100, 102, 103, 107, 108, 109, 112).

Напомена: у овом уџбенику смо у два текста (стр. 45-46, 104) наишли на појашњења значења нових ријечи и израза (помоћу преводне семантизације), која су специјално, намјенски издвојена на маргинама (са стране текста). У равни тих ученику непознатих руских форми дата је одговарајућа српска лексичка јединица, што сматрамо веома позитивним, јер указани поступак обезбјеђује ученицима семантизацију непознатих руских ријечи тако да не мора да прекида читање, тражећи њихово значење, него су му ти облици одмах појашњени, приступачни и самим тим и разумљиви.

У уџбенику Родничок 6, осим визуелне семантизације лексике, могли смо уочити и друге поступке тумачења значења ријечи, синтагми и реченица путем: а) преводне семантизације лексичких јединица („Словарик“, стр. 10, $15,16,23,25,30,37,42,43,48,51,55,56,57,70,73,75,79,86,92,95,98$, 104-105, 107, 109, 113, 118, 121); б) специјалних (намјенских) илустрација најчешће укључених у тематске рјечнике (одјећа и обућа, стр. 68-69; намирнице и посуђе, стр. 87); в) специфичног вида преводне семантизације ријечи 
смјештених на маргинама (стр. 58-59, 77, 78, 122-132 у рубрици текстова „Для тех, кто любит читать“"). У уџбеничкој структури књиге Родничок 7 лексичке јединице и изрази се појашњавају путем преводне семантизације у одјељцима: „Словарик“ (стр. 11, 21, 29, 34, 37, 40, 59, 61, 66, 67, 73, 77, 78, $79,84,85,98,101,102,111,112,120,125,133,135,137,139,140)$; „Запомни“ (стр. 91, 96, 101). У уџбенику Родничок 8 семантизација лексике се врши уз помоћ: а) преводне семантизације („Словарик“, стр. 14, 24, 36, 43, 53, 61, 73, 78, 82, 85, 95, 101, 107, 113, 121, 130, 135; „Запомни“, стр. 17, 43); б) путем специјалних (намјенских) илустрација најчешће укључених у тематске рјечнике (називи јела и пића, стр. 77). У овом уџбенику, поред парцијалних, ученику се на крају књиге нуди и кумулативан рјечник („Словарик“, стр. 159-162) и тематски рјечник („Тематические группы «словарных〉 слов“, стр. 163-164), који је за ученика од особите користи јер као репрезентативан и иновативан елеменат наведене уџбеничке структуре даје комплетан преглед свих тематски повезаних ријечи из уџбеника, уз обавезну колоритну и подстицајну илустрацију.

У вези са анализираним уџбеницима и семантизацијом лексике у њима могли смо уочити и то да је, осим назначених парцијалних рјечника у уџбеницима Орбита 5, 6, 7 и 8 као и Родничок 8, дат и кумулативан рјечник („Русско-сербский словарь“) у ком се врши преводна семантизација руске лексике и који омогућава ученицима самосталан рад над датим уџбеничким садржајима.

На основу цјелокупне анализе поменутих уџбеничких корпуса закључићемо да је поступак појашњавања и тумачења значења ријечи у основношколским уџбеницима, нажалост, великим дијелом запостављен и игнорисан, неријетко сведен на повремену семантизацију лексичких јединица, при чему су сви видови индивидуализације остали у највећем броју случајева неупотребљени. Шта би се могло урадити? Пожељно би било практиковати системско и планско појашњавање значења одређеног броја ријечи у склопу сваке лекције, примјењујући притом разне видове семантизације лексичких јединица и пружајући више методичких поступака и сугестија, дајући бројна рјешења за оне комуникативно и методички најважније лексичке јединице. У вези са овим остаје нам да претпоставимо да узрок запостављања семантизације руских лексичких јединица проистиче из намјера и интенција писаца анализираних уџбеничких структура да на тај начин граде, подстичу и развијају самостални рад, самостално учење и самообразовање ученика сопственим проналажењем и откривањем значења непознатих ријечи уз помоћ рјечника руског језика. 
3) Наша анализа свих наведених уџбеничких корпуса потврдила је сазнање да је индивидуализаиија преткомуникативног рада добрим дијелом остварена повезивањем више облика приказивања граматичког, фонетског и графијско-ортографског језичког материјала.

4) Сагледавајући индивидуализаиију у поступџима планирања и реализовања комуникативне активности, истаћи ћемо да је она остварена онда када комуникативни захтјеви, задаци и вјежбања могу бити ријешени на више различитих начина и могућности. Ученику се предочава неколико релевантних подстицаја, тако да он врши слободан избор оног или оних на које ће реаговати, или када се ученицима јасно представља који су дјелови задатка обавезни, а који факултативни, који су искључиво за усмени, а који за усмени и писмени рад. Да бисмо представили указано сада ћемо навести примјер из уџбеника Родничок 8 и Орбита 7:

* Разыграй со своим соседом/своей соседкой по парте сценки на следующие темы.

Употреби необходимые фразы. Затем поменяйтесь ролями.

(Исценирај са својим другом/својом другарицом из клупе следеће ситуације. Употребите одговарајуће исказе. Затим замените улоге.)

а) Представь, что ты просишь у своих родителей разрешения:

a) сходить в кино; б) остаться на ночь у друга/подруги; в) пригласить друзей на вечеринку.

(Замисли да молиш своје родитеље да те пусте да: а) одеш у биоскоп; б) останеш да преноћиш код друга/другарице; в) позовеш друштво на журку.)

б) Представь, что ты очень строгий учитель (строгая учительница). Придумай несколько запретов для своих учеников.

(Замисли да си веома строг наставник (строга наставница). Смисли неколико забрана за своје ученике.) (Родничок 8, стр. 52)

* Разыграйте диалоги.

1) Tbь звонишь своему другу/подруге по телефону и сообщаешь, что получил(а) от него (неё) фотографии.

2) Ть звонишь другу (подруге) и приглашаешь его (её) прийти к тебе вечером. Он (она) соглашается. (Орбита 7, стр. 11)

Да наведемо и то да би индивидуализација у оваквим случајевима била много израженија, ако би у задацима, захтјевима и вјежбама била дата и могућност самог избора. Даћемо као примјер једно такво вјежбање.

* Если ты прочитал(а) эти две шутки, то наверное рассмеялся / рассмеялась. Ведь шутки тому и служат. Но иногда, посмеявшись, можно и подумать о героях шутки. Давай поговорим об этих двух мальчиках! 
Какие они? (Нежный, внимательнылй, добрый, заботливый, грубый, злой)

Как ты думаешь, есть ли у них дома свои питомиьь?

А как они относятся к людям (старым, молодым, беспомощьным)? (Орбита 7, стр. 174)

Могућност самог одабира форме рада (писмена или усмена израда) доминира у највећем броју комуникативних вјежбања. Тачније, она је присутна свуда гдје се не изражава изричита неопходност писменог рјешавања.

5) Индивидуализација и диференцијација се остварују и путем избора, издвајања и селектирања у прочесима обраде и тумачења предложсени текстуалних садржаја. Текстови, одвојени у посебне дјелове уџбеничких параграфа, намијењени, конципирани и осмишљени за ученике који остварују боље резултате током школовања и који посједују већи степен мотивисаности за усвајање руског језика као страног, нијесу обавезни за све ученике.

У анализираним уџбеничким серијама грађа која је намијењена за индивидуални или диференцијални рад није на неки особит начин означена, већ се очекује да селекцију и одабир учини сам наставник. Због великог броја текстова и њихове богате садржајности немогуће у предвиђеном фонду часова прећи и обрадити сву текстуалну материју са цјелокупном разредном групацијом. Такви текстови су, дакле, у анализираним уџбеничким корпусима издвојени у специјалне дјелове уџбеничких параграфа у виду додатних блокова смјештених на крају књиге. На њих наилазимо у уџбеничкој серији Орбита у одјељку „Тексты для дополнительного чтения“, стр. 192-205 (Орбита 7), а у анализираној серији Родничок наилазимо на одјељак ,Для тех, кто любит читать““ на стр. 122-132 (Родничок б) и стр. 132-143 (Родничок 7).

Индивидуализација и диференцијација се могу постићи и препознати и у самом редосљеду приказивања и усвајања уџбеничке материје (линеарни редосљед -,„лекција за лекцијом“ и нелинеарни редосљед -,,тема за темом“). У уџбеничким корпусима који су подвргнути експертизи третира се перманентно усвајање нових језичких знања, али и стална активизација старих. Процес овладавања граматичком грађом у свим анализираним уџбеничким структурама је линеаран, јер се она презентује ученицима уз помоћ принципа „од лакшег ка тежем“, тј. „од простијег ка сложенијем“, тако да се свака нова тема и јединица из граматике заправо ослања на претходну и сама чини ваљан темељ и адекватну припрему у процесу учења сваке сљедеће лекције.

Када говоримо о тематско-ситуативном плану, нагласићемо да ту могу постојати извјесне варијације, осим ако аутори уџбеника особито не истакну нешто другачије. 
Уџбеник треба да у својој структури обухвати она конструкцијска рјешења која ће подстицати индивидуализацију способности самоконтроле, самокорекције и самообразовања код ученика.

У уџбеничким корпусима који су подвргнути нашој анализи нијесмо уочили такав методички апарат који би у потпуности омогућио ваљано и правилно изграђивање и развој навике самоконтроле као важне компоненте индивидуализације наставе.

Индивидуализацији наставе уз помоћ уџбеника умногоме доприноси и сам процес персонализаиије излагања. У текстовима, коментарима, инструкцијама за израду вјежбања, инструктивним текстовима, скалама за самосталну валоризацију остварења, писац уџбеника се непосредно обраћа сваком појединачном ученику (најчешће користећи „ти“ варијанту и инклузивни императив типа: погледајмо, прочитајмо, запитајмо се...), настојећи да га покрене и интелектуално и емоционално-доживљајно (Кончаревић 2009: 169). У вези са овим осврнућемо се на тенденцију сагледавања проблематике успостављања индивидуалног контакта између аутора школске књиге и ученика.

Аутор уџбеничких структура конципира уџбеничку грађу по мјери више категорија ученика којима су оне упућене, он увијек узима у обзир индивидуалне разлике у сфери мотивације, према афинитетима, нивоима предзнања ученика, когнитивним стиловима (Плут 2003: 232-235; Кончаревић 2009: 169).

Сада ћемо указати на то да су за рад под контролом и надзором наставника намијењени уџбеник, магнетофонска вјежбања и апликације за фланелограф, док су за индивидуални рад предвиђени - радна свеска, рјечник и граматика. То нам указује на чињеницу да се индивидуализација наставе и учење страног језика могу остварити и кроз друге компоненте уџбеничког комплета. У овом сегменту посебно ћемо истаћи значај Радне свеске и Приручника за наставнике. Радна свеска обухвата „серију питања, задатака, проблема, радних налога које ученик решава или извршава без непосредне помоћи наставника и о томе бележи своје одговоре, запажања и искуства на одређеним, за то предвиђеним местима. Осим садржајне повезаности са уџбеником, радна свеска у свему другом (...) умногоме одступа од уџбеника. Већ и по самој њеној концепцији, радна свеска је, пре свега, средство намењено самоучењу, самораду, самоконтроли и самоевалуацији ученика, па сходно томе поседује наглашену индивидуализациону функцију“ (Кончаревић 2009: 169). Писци радних свезака неријетко губе из вида нужност истовременог спровођења диференцијације рада кроз понуђене садржаје (они често замишљају једног просјечног ученика „насамо“ са радном свеском, 
умјесто сагледавања и узимања у обзир многих других релевантних могућих приступа).

Сагледавајући структуре радних свезака анализираних уџбеничких корпуса, указаћемо на то да смо уочили како њихов примарни циљ није превасходно ,утврђивање уџбеничких садржаја, него шири интелектуални и комуникативно-говорни развој ученика, њихово мотивисање за учење страног језика и обликовање навике самоучења и саморада, радне свеске не остварују круту садржајну повезаност са уџбеником, па се стога у њима нигде и не срећу експлицитна указивања на поједине делове параграфа“" (Кончаревић 2002: 86).

Интегрисање анализираних радних свезака и уџбеника постигнуто је паралелном рубрикацијом: у радним свескама садржина је постављена према уџбеничким параграфима (сваком параграфу одговара додатни број вјежбања из радне свеске).

Слична ситуација је и у приручнициима за наставнике. Њихов примарни циљ је да пруже информације и инструкције наставницима усљед операционализације материјала у уџбенику, да планирају и организују активности наставника и ученика у раду са школском књигом. Најчешће се у њима даје интерпретација уџбеничке грађе по систему лекција - час, уз детаљније разрађене сценарије одвијања сваког часа у реализацији наставног процеса. Приручник за наставнике и уџбеник остварују најјачу везу (рубрикација параграфа у приручнику идентична је оној у уџбеничкој структури, те су тако аналогни и њихови методички садржаји, употреба радне свеске, аудитивних материјала).

Радећи на анализи наведених уџбеничких структура и њихових пратећих компонената, могли смо примијетити да се ученик усмјерава на $a y-$ дио-материјале уз помоћ симбола који му пружају информацију које елементе уџбеничке текстотеке може да одслуша код куће (што умногоме доприноси повећању квалитета у процесу оваладавања руским језиком као страним и самим тим и обезбјеђује укључивање још једног важног елемента у индивидуални рад). Међутим, оно што смо могли уочити јесте и изостављање могућности чврићег интегрисања школске књиге и аудио-материјала, што се могло остварити укључивањем разноврсних вјежбања типа:

* Пажљиво послушајте и одредите која илустрација (фотографија, цртежс, слика) најбоље одговара садржају аудио-текста итд.

Да би се ваљано и компетентно организовао и реализовао индивидуални рад ученика, од особитог значаја је тенденција у којој мјери уџбеничка структура, уз помоћ система усмјеравања и упућивања, „остварује контакт" са осталим елементима уџбеничког комплета. Бавећи се анализом структура наведених школских књига, могли смо примијетити и тенденцију 
да су писци уџбеника изоставили могућност остваривања чвршће повезаности и спајања уџбеника са осталим компонентама уџбеничких комплета, као и упознавања и увођења ученика у њихове садржаје и структуру, истицање значаја и функционалности, чиме би их оспособили за самосталан рад, учење и контролу, подстичући и развијајући на тај начин код њих и способност служења књигом и рјечником.

Радећи на утврђивању степена разликовања задатака намијењених за рад на часу и за самосталну (домаћу) израду у анализираним уџбеничким корпусима, скренућемо пажњу на сљедеће:

- Диферениијаџија између домаћих и иколских задатака није истакнута ни у једној анализираној уцбеничкој структури из назначених уцбеничких серија.

\section{2. ЗАКљУЧАК}

Сагледавајући све наведене теоријске аспекте индивидуализованог уџбеника руског језика, може се приступити експертизи и процјени сваког уџбеничког остварења за руски језик који се активно користи за основношколску узрасну формацију у српској/црногорској и другим социокултурним говорним срединама. Иако индивидуализовани садржаји наставе у наведеним анализираним школским уџбеницима и систем конструкцијских рјешења неријетко нијесу у складу са дометима теоријских модела индивидуализованог наставног процеса (особити пропусти и недостаци по питању сагледавања апаратуре индивидуализације у анализираним уџбеничким корпусима огледају се у једноличности, ограничењима и оскудности у сфери семантизације лексичких јединицуа, у недовољној диференщијацији задатака намијењених за разредни и домаћи рад и остваривању контролно-корективне функције сваке анализиране уибеничке структуре), ипак је, у односу на уобичајене уџбенике из прошлости, у савременим уџбеничким структурама јасно уочљиво присуство појединих елемената индивидуализације, а бројна релевантна и посве корисна и важна конструкцијска рјешења обезбјеђују стварање адекватних околности за постизање разноврсних стратегија и нивоа индивидуализације, што чини основни предуслов преласка наставе страног језика као поучавања у наставу која обезбјеђује самостално усвајање језика, остварење већег степена задовољења когнитивних и комуникативних потреба сваког појединца у процесу учења језика, а тиме и подстицање сваког ученика на самообразовање, самоактуализацију и саморазвој као императив савремене наставе и времена у којем живимо. 


\section{ЛИТЕРАТУРА}

Арутюнов, А. Р. (1987). Конструирование и экспертиза учебников русского языка для иностранцев. Москва: Институт русского языка им. А. С. Пушкина.

Кончаревић, К. (2002). Савремени уцбеник страног - руског језика: структура и садржај. Београд: Завод за уџбенике и наставна средства.

Кончаревић, К. (2009). “Функција индивидуализације и диференцијације У уџбенику страног (руског) језика: теоријски принципи и конструкцијска решења“, у Individualizacija i diferencijacija u nastavi stranog jezika i književnosti, прир. Јулијана Вучо и Биљана Милатовић (Никшић: Филозофски факултет): 162-171.

Плут, Д. (2003). Уцбеник као културно-потпорни систем. Београд: Завод за уџбенике и наставна средства.

Радошевић, Н. (1970). Функиија школског уцбеника у светлости савремене науке. Београд: Научна књига.

\section{ИЗВОРИ}

Пипер, П., Петковић, М., Мирковић, С. (2007). Орбита - руски језик за 5. разред основне школе. Београд: Завод за уџбенике и наставна средства. Пипер, П., Петковић, М., Мирковић, С. (2008). Орбита - руски језик за 6. разред основне школе. Београд: Завод за уџбенике и наставна средства. Пипер, П., Петковић, М., Мирковић, С. (2005). Орбита - руски језик за 7. разред основне школе. Београд: Завод за уџбенике и наставна средства.

Пипер, П., Петковић, М., Мирковић, С. (2010). Орбита - руски језик за 8. разред основне школе. Београд: Завод за уџбенике и наставна средства. Пипер, П., Петковић, М., Мирковић, С. (2007). Орбита - руски језик за 5. разред основне школе: радна свеска. Београд: Завод за уџбенике и наставна средства.

Пипер, П., Петковић, М., Мирковић, С. (2008). Орбита - руски језик за 6. разред основне школе: радна свеска. Београд: Завод за уџбенике и наставна средства.

Пипер, П., Петковић, М., Мирковић, С. (2009). Орбита - руски језик за 7. разред основне школе: радна свеска. Београд: Завод за уџбенике и наставна средства.

Пипер, П., Петковић, М., Мирковић, С. (2010). Орбита - руски језик за 8. разред основне школе: радна свеска. Београд: Завод за уџбенике и наставна средства. 
Пипер, П., Петковић, М., Мирковић, С. (2007). Орбита - руски језик за 5. разред основне школе: приручник за наставнике. Београд: Завод за уџбенике и наставна средства.

Пипер, П., Петковић, М., Мирковић, С. (2008). Орбита - руски језик за 6. разред основне школе: приручник за наставнике. Београд: Завод за уџбенике и наставна средства.

Пипер, П., Петковић, М., Мирковић, С. (2005). Орбита - руски језик за 7. разред основне школе: приручник за наставнике. Београд: Завод за уџбенике и наставна средства.

Пипер, П., Петковић, М., Мирковић, С. (2010). Орбита - руски језик за 8. разред основне школе: приручник за наставнике. Београд: Завод за уџбенике и наставна средства.

Поповић, Љ., Гинић, Ј. (2007). Родничок - руски језик за 5. разред основне школе. Београд: Завод за уџбенике.

Поповић, Љ., Гинић, Ј. (2008). Родничок-руски језик за 6. разред основне школе. Београд: Завод за уџбенике.

Поповић, Љ., Гинић, Ј. (2009). Родничок-руски језик за 7. разред основне школе. Београд: Завод за уџбенике.

Поповић, Љ., Гинић, Ј. (2010). Родничок-руски језик за 8. разред основне школе. Београд: Завод за уџбенике.

Поповић, Љ., Гинић, Ј. (2007). Родничок - руски језик за 5. разред основне школе: радна свеска. Београд: Завод за уџбенике.

Поповић, Љ., Гинић, Ј. (2008). Родничок - руски језик за 6. разред основне школе: радна свеска. Београд: Завод за уџбенике.

Поповић, Љ., Гинић, Ј. (2009). Родничок - руски језик за 7. разред основне школе: радна свеска. Београд: Завод за уџбенике.

Поповић, Љ., Гинић, Ј. (2010). Родничок - руски језик за 8. разред основне школе: радна свеска. Београд: Завод за уџбенике.

Поповић, Љ., Гинић, Ј. (2007). Родничок - руски језик за 5. разред основне школе: приручник за наставнике. Београд: Завод за уџбенике.

Поповић, Љ., Гинић, Ј. (2008). Родничок - руски језик за 6. разред основне школе: приручник за наставнике. Београд: Завод за уџбенике.

Поповић, Љ., Гинић, Ј. (2009). Родничок - руски језик за 7. разред основне школе: приручник за наставнике. Београд: Завод за уџбенике. 


\title{
Natalija Brajković
}

\section{THE APPARATUS OF INDIVIDUALISATION IN THE RUSSIAN LAN- GUAGE TEXTВOOKS ОРБИТА AND РОДНИЧОК AND OTHER ELEMENTS OF THESE TEXTBOOKS SETS}

\begin{abstract}
Summary
This paper examines eight textbooks of the Russian language, including the components of the analyzed textbook structures. Textbook sets such as „Орбита“ and „Родничок“ have been used in primary schools in Montenegro and Serbia during the last twenty years. The aim of this paper is to analyze all relevant and useful segments of the textbooks in order to help establish the design of a textbook used in foreign language teaching and learning that would be more efficient and have better quality. Our goal is to make individualization and differentiation more realistic and proficient, to set the principles within the textbooks and to emphasize numerous research results of the individualization based on the evaluation of the textbook corpus. We also offer a set of constructive suggestions aimed both at creating proper opportunities for the use of different strategies and at achieving different levels of individualization. According to the results and the comparison of these textbooks with those that were previously used, the main conclusion is that there is an evident presence of certain elements of individualization. The paper also gives numerous relevant, useful and important suggestions which could help generate adequate circumstances for promoting various strategies and achieving different levels of individualization.
\end{abstract}

Key words: individualization, differentiation, a Russian language textbook, the teaching process, lexical units, primary school level. 